\title{
Motivation chart as a supporting tool in pediatric dentistry
}

\author{
Quadro de motivação como ferramenta coadjuvante na odontopediatria
}

\author{
Carolina VASCONCELLOS 1 \\ José Carlos Petorossi IMPARATO' \\ Karla Mayra REZENDE ${ }^{1}$
}

\begin{abstract}
Infant fear and anxiety are two feelings that cause stress in pediatric dental treatment. Many management techniques have been described in the literature, with the aim of controlling this anxiety and fear that are ultimately a big challenge for the dental surgeon. The aim of this study is to present a clinical case of a five-year-old child who would not cooperate with the dental treatment. To this end, an incentive chart was devised that is specific for treatment. The chart focuses on encouraging the child to comply with rules in the pediatric dentist office and, as the child completes his objectives, the chart is filled with happy faces and at the end of the appointment, depending on the outcome, the patient is rewarded with something. We concluded that the use of the incentive chart was particularly satisfactory in terms of the patient's conduct and developing maturity over the course of his dental treatment and it may be an additional option to use as an adjunct in the approach to behavior in private or public dental clinics, and even in Universities.
\end{abstract}

Indexing terms: Anxiety. Pediatric dentistry. Psychology.

\section{RESUMO}

O medo e ansiedade infantil são dois sentimentos que causam estresse no tratamento odontopediatrico. Muitas técnicas de condutas e manejo são descritas na literatura onde principalmente o objetivo é controlar esse comportamento acaba sendo um grande desafio para cirurgião dentista. O objetivo deste trabalho é apresentar um caso clinico de uma criança de 5 anos de idade que não cooperava com o tratamento odontológico por apresentar medo e ansiedade de experiências passadas. Para isso, foi elaborado um quadro de incentivo, especifico para atendimento odontológico, para ajudar a criança a perceber a sua rotina e auxiliar na introdução de atividades diárias. O uso do quadro de incentivo, foi bastante eficaz na conduta e amadurecimento do paciente durante o tratamento odontologico. O uso desse quadro acaba sendo uma alternativa a mais, a ser utilizada como abordagem de comportamento no consultório particular, público ou mesmo nas Universidades.

Termos de indexação: Psicologia. Odontopediatria. Ansiedade.

\section{INTRODUCTION}

Young children often become anxious when faced with dental treatment, occurring in around $10-20 \%$ of children and teenagers. It is a form of stress and has a negative impact on the quality of life of patients and their parents or guardians, and may be associated with poor oral health'.

Pediatric dental treatment is based on the relationship with the child and its parents. The secret to controlling fear and anxiety when faced with the most diverse treatments is talking, trust between professional and patient and satisfying children's curiosity in the dental environment ${ }^{2-3}$.
The most frequently used non-pharmacological management techniques in pediatric dentistry are as follows: verbal communication, tell-show-do, non-verbal communication, positive reinforcement, distraction, presence or absence of parents and physical restraint. Each technique has an indication and age when it is best used ${ }^{2,4}$.

Another factor to consider is the professional's appearance. Children develop an impression of their dentist before any verbal communication, based on appearance. This was the theme of the study by Ravikumar et al. ${ }^{5}$. They conducted a cross-sectional study on 534 children aged between 6 and 11, in schools and in dental clinics. The children were divided into three groups according to age. Photographs of the dentist in his/her white coat, surgical

\footnotetext{
Faculdade São Leopoldo Mandic, Curso de Odontologia, Programa de Pós-Graduação em Odontologia - Área de Concentração Odontopediatria. Rua José Rocha Junqueira, 13, Swift, 13045-755, Campinas, SP, Brasil. Correspondência para / Correspondence to: KM Rezende. E-mail: <karla.rezende@ usp.br>
} 
overalls and casual clothes were shown and the level of anxiety was evaluated using the Children's Dental Anxiety Scale [MCDAS (f)]. The authors concluded that the smaller children preferred to be seen by dentists wearing casual clothes. The older children preferred their dentist to wear the white coat and surgical overalls. The white coat was the uniform of choice for the majority of children in the school environment, but the level of preference for surgical overalls was higher in the dental clinic environment.

Children's attitudes and habits are molded in their living environments, and everything learned in early infancy is carried forward to the later stages of life, therefore motivation in schools, together with the professional's skill, is of huge importance to the children ${ }^{6}$. Of the factors that determine anxiety in preschool children, one is related to children who have three or more siblings. This might be explained by two factors. Firstly because children in larger families could be directly or indirectly exposed to information about dental treatment provided to their siblings, and secondly they might have observed their siblings appearing anxious during dental treatment, causing negative thoughts that could have an impact on their anxiety about dental treatment ${ }^{7}$.

Pediatric dentists should be aware of the stages of psychological evolution in children and how to build a relationship of trust with their patients, remembering that where children are involved, actions and words may contribute to their personality, lead to greater manual dexterity and performing the correct diagnosis, in order then to achieve successful treatment ${ }^{8-9}$. The professional who can tell the difference between each of these phases and understand the needs of the child, will make the treatment more comfortable and bring more security and tranquility to the parents. It will also help the professional persevere with his/her work, not feel frustrated or guilty when the child cries or resists treatment ${ }^{10}$.

Barreto et al. ${ }^{11}$ conducted a study into the prevalence of anxiety in children aged between six and seven. To this end, the authors applied questionnaires with 1,367 children in public and private schools. The results showed that $54.4 \%$ of children had some form of anxiety related to the dental consultation, of which $74.1 \%$ were considered light to moderate, and there was no statistically significant difference in terms of the children's sex. The authors concluded that anxiety was high in children that had never before visited the dentist.

Dental clinics do not always provide a fun environment, for example in city halls, faculties, etc., therefore new options are required to help with this psychological process. One alternative in this type of environment is to use a system of extrinsic motivation, in other words, when emotions that are either pleasurable or disagreeable can be generated by the reward received after a certain action, based on positive reinforcement. They are used to change specific behavior and reinforce attitudes in a positive way, actions which will result in some prize or reward.

One alternative for changing a child's behavior over a short period of time is to use an incentive chart. This is a technique that combines positive reinforcement with prizes. Every time a goal is completed, the child gets a smiley that shows (happy or sad) behavior. On completion of the goal, the child gets a gift. This happens because human behavior can be modified by means of conditioning through reinforcement and, over time, this behavior can become a habit ${ }^{12}$.

The use of an incentive chart is frequently employed in the area of teaching and education with the aim of establishing rules and limits. If the child does not attain the proposed objective, a punishment is applied such as not being allowed to watch TV, play a video game and/or use the tablet, for example. When the objective is reached, a prize is awarded as a form of encouraging the good behavior to continue.

Even though it may be seen as effective in the field of education, there is nothing similar to the incentive chart in pediatric dentistry. Recognizing that this technique may be very useful, the aim of this study was to create an incentive chart method that focuses on the area of pediatric dentistry and to ascertain its applicability in the education of oral health care both outside and inside the dental clinic environment. Thus, the aim of this study was to use the motivation chart developed for this purpose, in order to investigate its contribution to the conditioning and psychological protocols for dental treatment.

\section{CASE REPORT}

Five-year old, male patient presented to the dental clinic accompanied by his mother, as he had several caries lesions and was not being very cooperative. According to the mother, another professional had attempted to treat him, but without success, simply using cariostatic material on the molars so that the caries lesions would not deteriorate further (Figure 1). 


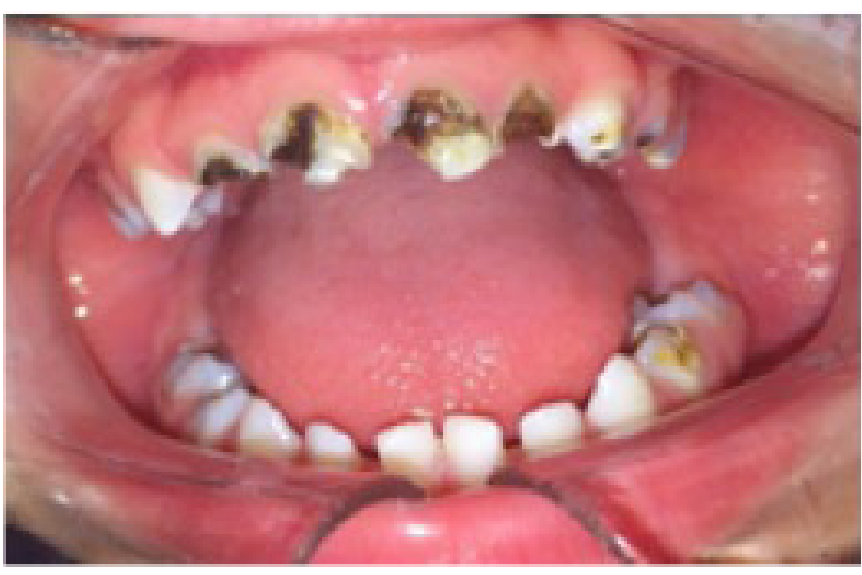

Figure 1. Initial clinical aspect of the child's oral condition.

Observing the patient's arrival at the clinic (remote conditioning), it was obvious that he was very shy, clinging to his mother. After a lot of discussion, he sat down in the dentist's chair, but it was difficult to establish any kind of communication between the dentist and child (Figure 2).

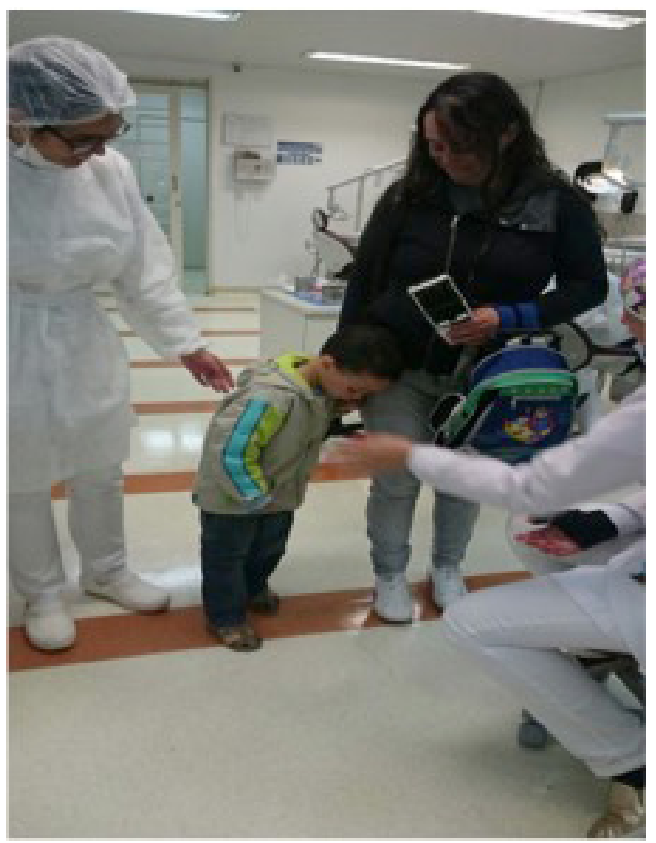

Figure 2. Difficult to establish any kind of communication between the dentist and child.

Before commencing the procedure, the dental surgeon made his first contact with the patient by way of conversation, thus identifying the child's psychological profile, but without success. So for the second session, of the diverse psychological procedural techniques available, the plan was to make use of the motivation chart. The aim was to place three figures relating to dental behavior and for each successful phase, the patient would get a smiley face on which the dentist would do a drawing. For three smiley faces, he would get a present. If he did not attain the objective, the dentist would continue the treatment, give him a hug and explain why he didn't get the prize (Figure 3).

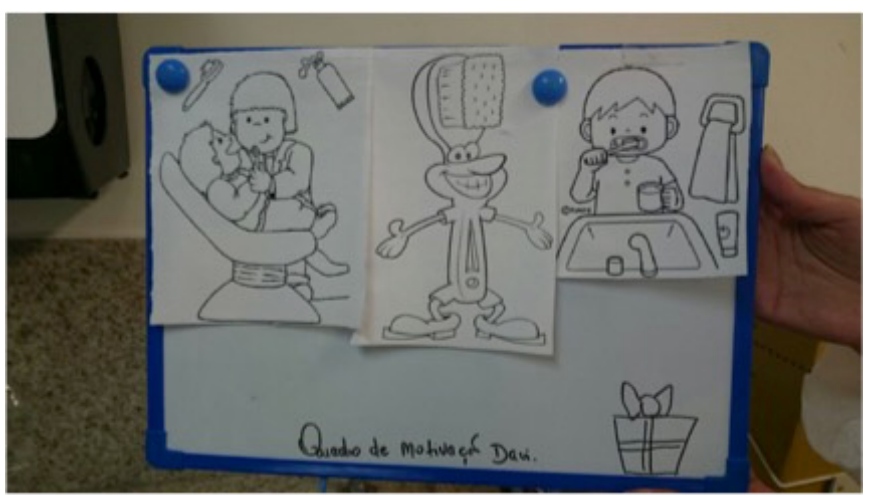

Figure 3. Motivation framework idealized for the research.

The chart was shown to the patient at the second appointment, in which the dentist explained how it would work and, though rather reluctant, the boy did pay attention. The dentist began the consultation showing the materials he would be using, using the tell-showdo technique, in which it was possible to carry out the procedures, albeit using a degree of guile. His first prize was a box of playdough, and when the dentist gave it to him, although very shy, he was clearly happy. At the end of the consultation, the dentist congratulated him on his behavior and explained that if he behaved during the next few sessions he would get more presents (Figure 4).

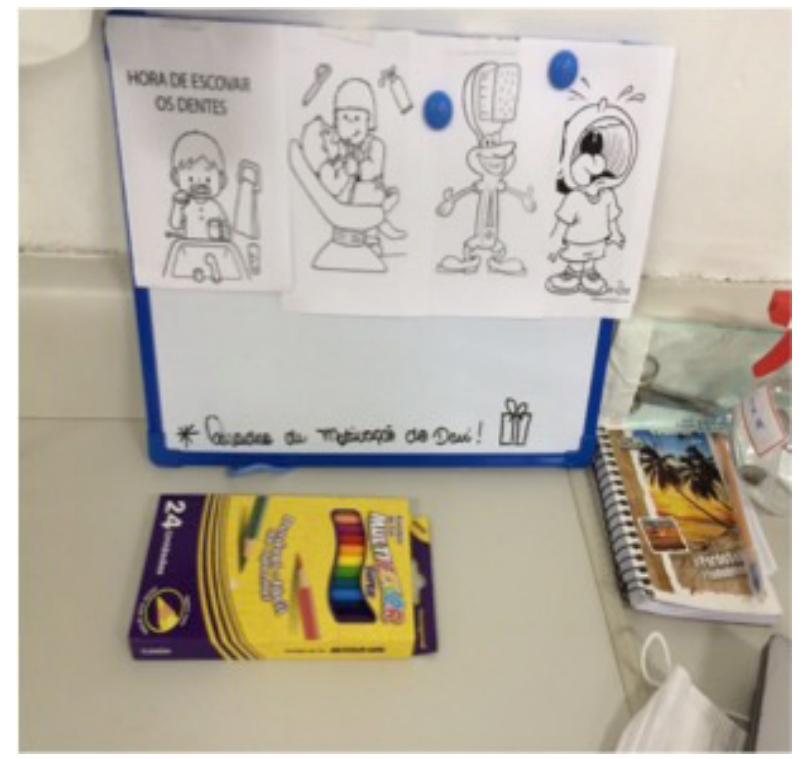

Figure 4. Added by another figure and showing the award. The interesting thing about this picture is that it is flexible according to the child's behavior. 
For the third consultation, the dentist added another image, about crying, and explained to the boy that to get another smiley face and the present, he must not cry. The patient arrived at the third appointment in a very cooperative mood and it was possible to perform the required $x$-rays. The patient behaved very well, getting a smiley face. As he was reportedly in pain and the $x$-ray did not show any pulp damage, it was decided to perform atraumatic restorative treatment (ART) on teeth 74 and 75. During this partial removal, he behaved very well and received yet another smiley face. When it was time to restore the tooth with ionomer, the patient did not like the taste of the polyacrylic acid solution and became uncooperative. He cried a lot, struggled and vomited a few times, but finally fluoride was applied so that he could manage to protect the cavity a little. At the end of the consultation, it was explained to the child that he had won two smiley faces and two sad faces, so he would not get his present and was encouraged to improve for the next appointments (Figure 5).

In the fourth appointment, ART was performed on tooth 55 , the patient behaved well and, at the end, got his reward.

The patient arrived in cooperative mood for the fifth appointment, though the mother was very troubled by the state of her son's mouth, saying that he was unable to eat the things he enjoyed as it caused him pain. The chart was shown to the patient once again. As the x-rays had already been taken, it was decided to carry out ART on teeth 74 and 75 . The patient complained a little, but he was scolded and the purpose of the chart was once again explained to the patient. He then calmed down and it was possible to perform the ART (Figure 6). At the end of the appointment, the patient got his four smiley faces and won a prize (a box of colored pencils), and now less shy, he demonstrated that he liked the present, and we finished the session with positive reinforcement.

\section{DISCUSSION}

The adaptation of the patient's behavior in the pediatric dental surgery is achieved using procedures that combine the technical ability of the professional and good interpersonal behavior. Children's levels of anxiety in consultations may vary according to age, parents' anxiety, distorted information from siblings or friends or even the imaginary of the unknown of what pediatric dental treatment might be like ${ }^{7,11,13}$. In the case presented here, the five-year-old child had endured a bad experience with a professional who was not a pediatric dentist, in which he did not manage to perform a treatment and the mother proved to be less than cooperative.

For the pediatric dental consultation to be able to rely on the patient's cooperation, it is necessary to understand and respect each phase of the child's development ${ }^{13}$. Therefore, prior to beginning any dental treatment, it was necessary to use behavioral management techniques in order to reduce the child's and mother's fear and anxiety during the consultations ${ }^{13}$. In addition to the psychological procedural techniques, the professional must have above all the skills to communicate, of rapport and knowing how to listen, always with the aim of allaying the patient's anxiety and fear, teaching the patient to cope with situations and to generate trust ${ }^{2,14-16}$. Of the abovementioned psychological management techniques, the tell-show-do, distraction and molding techniques are seen as good alternatives for reducing anxiety and fear in children during dental treatment, as indicated by the studies of Rezende et al. ${ }^{2}$ and Fakhruddin et.al. ${ }^{17}$. Unlike in the literature, however, these psychological tactics were not successful in permitting adequate dental treatment and the attempt to become the patient's friend was almost always hampered, mainly due to the mother's conduct. Based on the understanding of psychosocial and affective development in children's early infancy, the presence of the mother is advantageous during the consultations. However in the clinical case described here, the child, at five years of age, was immature for his chronological age. Thus the mother was present during the treatment with the aim of reducing anxiety and maintaining the child's safety. This was only possible, however, because she was directed to keep her composure and avoid talking to or stroking her son during treatment, otherwise she would have to leave the clinic in order not to cause any more anxiety or insecurity for her son $4,13,16$

In one study of child psychological behavior, it is stated that children already have a better level of understanding by the age of four, so physical restraint is not widely used, but rather the establishment of ground rules for generating trust and setting behavioral limits ${ }^{15}$. As the psychological profile of the patient had already been delineated at the time of the first appointment, we knew that some extra motivation would be required to succeed in controlling his fear/anxiety, hence the proposal of the motivation chart. The motivation chart is used a lot in the area of education and learning at home and in school, with the aim of encouraging compliance with rules. Every time a smiley face is achieved and, depending on achievement, 
it will be filled with decorative stickers with sad or smiley faces and, depending on the outcome, the child will be rewarded with a present, an excursion or something else he likes and, if he does not comply with these little rules, he could have something he likes taken away, such as a videogame, TV or going to the cinema. Ultimately, it is a combination of techniques used in the psychological management of dental treatment, such as tell-show-do and verbal communication $2,14,16$. Moreover, the incentive chart can help the child to understand his routine and assist in introducing daily activities. Based on this theory and observing the difficulty of conditioning the patient during dental treatment, a motivation chart with an oral health bias was introduced. This chart was developed by us and is based on the child's behavior. The first time, three tasks are inserted, such as coming to the appointment with teeth already brushed at home, remaining in the chair with the mouth open so the dentist can examine the teeth and letting the dentist brush and fix any open tooth. In the first session, the chart was explained to the child and it was placed in his line of vision. Thus, every time the dentist managed to complete a task, a (sad or happy) face would be drawn on the chart. The first appointment was satisfactory. Although the child allowed himself to be examined, he did throw a tantrum. Then at the second visit, another figure was added in which it was explained that, in addition to performing the three tasks, they had to be completed without crying. At the third appointment, the behavior was going well until, when applying the etching acid to restore the tooth with $\mathrm{GIC}$, the child felt a bad taste and began crying and did not cooperate. The treatment could not be finished. With a total of just two smiley faces, the child did not get his prize and he was advised at the end of the consultation that his behavior would need to improve and so he received a gentle rebuke so that he might improve next time. All of these attitudes and behaviors were so that the child might be encouraged and motivated to show good behavior in future appointments. This was indeed the result because in the last appointment, the child's behavior was already more placid and he was

\section{REFERENCES}

1. Marshman Z, Morgan A, Porritt J, Gupta E, Baker S, Creswell $C$, et al. Protocol for a feasibility study of a self-help cognitive behavioural therapy resource for the reduction of dental anxiety in young people. Pilot Feasibility Stud. 2016;2:13.

2. Rezende KM, Bönecker M, Côrrea MSP. Protocolo clinico no atendimento de bebês. In: Imparato JCP, colaborador. Anuário less shy, happy with the prize he received at the end of the treatment. It is of paramount importance that, in each of these phases, the dentist praises the patient. Knowing how to praise at the right moment shows the child about recognition through his/her efforts when presented with the situation to which he/she is being subjected.

This study was new, in the sense that it brought together psychological, teaching and educational learning within the dental clinic. All children feel the need to be loved and to be capable. If, during treatment, the professional demonstrates sensitivity and affection, some of the anxiety and fear will be allayed. There is no general rule for the procedure, and good sense and intuition on the part of the professional are needed and are fundamental for better management of pediatric dental treatment $2,6,9-10,12,14,16$.

The use of the incentive chart was particularly effective in the behavior and developing maturity of the patient over the course of treatment. Perhaps a slight delay in the procedure, spacing out the time between treatments (30 days). Maybe, if the treatment was done on a weekly basis, this expedient would be more effective but anyway, in the end, the use of this chart is an additional option to be used as an approach to behavior in private and public dental clinics, and even in Universities.

\section{CONCLUSION}

The aim of the incentive chart presented in this study was to demonstrate rules and responsibilities in a fun way and to create a healthy routine. In this case, it showed an alternative option in psychological management when carrying out dental treatment.

\section{Collaborators}

C VASCONCELLOS, clinical execution. JCP IMPARATO, reading and final correction. KM REZENDE, idealizer of the project and orientation in the conduct and clinical and writing execution.

de Odontopediatria: integrada e atual. 2. Santa Bárbara D'Oeste: Napoleão; 2015. p. 168-75.

3. Abanto J, Rezende KM, Carvalho TS, Correa FN, Vilela T, Bonecker $\mathrm{M}$, et al. Effectiveness of tooth wipes in removing babies' dental biofilm. Oral Health Prev Dent. 2012;10(4):31926.

4. Al-Khotani A, Bello LA, Christidis N. Effects of audiovisual distraction on children's behaviour during dental treatment: 
a randomized controlled clinical trial. Acta Odontol Scand. 2016;74(6):494-501. doi: 10.1080/00016357.2016.1206211

5. Ravikumar D, Gurunathan D, Karthikeyan S, Subbramanian E, Samuel VA. Age and environment determined children's preference towards dentist attire - a cross - sectional study. J Clin Diagn Res. 2016;10(10):ZC16-ZC9. doi: 10.7860/ JCDR/2016/22566.8632

6. Soares FC, Lima RA, Santos Cda F, de Barros MV, Colares V. Predictors of dental anxiety in Brazilian 5-7 years old children. Compr Psychiatry. 2016;67:46-53. doi: 10.4103/jispcd. JISPCD_19_17

7. Abanto J, Vidigal EA, Carvalho TS, Sa SN, Bonecker M. Factors for determining dental anxiety in preschool children with severe dental caries. Braz Oral Res. 2017;31(0):e13.

8. Staberg M, Noren JG, Gahnberg L, Ghaderi A, Kadesjo C, Robertson A. Behavioural characteristics in externalising children with low and elevated risk for dental caries. Eur Arch Paediatr Dent. 2016;17(6):475-84.

9. Blomqvist $\mathrm{M}$, Ahadi S, Fernell E, Ek U, Dahllof G. Dental caries in adolescents with attention deficit hyperactivity disorder: a population-based follow-up study. Eur J Oral Sci. 2011;119(5):381-5. doi: 10.1111/j.1600-0722.2011.00844.x

10. Nelson TM, Huebner CE, Kim A, Scott JM, Pickrell JE. Parentreported distress in children under 3 years old during preventive medical and dental care. Eur Arch Paediatr Dent. 2015;16(3):28390. doi: 10.1007/s40368-014-0161-9

11. Barreto KA, Dos Prazeres LD, Lima DS, Soares FC, Redivivo RM, da Franca $C$, et al. Factors associated with dental anxiety in Brazilian children during the first transitional period of the mixed dentition. Eur Arch Paediatr Dent. 2017;18(1):39-43. doi: 10.1007/s40368-016-0264-6
12. Britto PR, Lye SJ, Proulx K, Yousafzai AK, Matthews SG, Vaivada $T$, et al. Nurturing care: promoting early childhood development. Lancet. 2017;389(10064):91-102. doi: 10.1016/S01406736(16)31390-3

13. Blazei RW, lacono WG, McGue M. Father-child transmission of antisocial behavior: the moderating role of father's presence in the home. J Am Acad Child Adolesc Psychiatry. 2008;47(4):40615. doi: $10.1097 / \mathrm{CHI} .0 \mathrm{~b} 013 \mathrm{e} 3181642979$.

14. Greenbaum PE, Lumley MA, Turner C, Melamed BG. Dentist's reassuring touch: effects on children's behavior. Pediatr Dent. 1993;15(1):20-4.

15. Wergeland GJ, Fjermestad KW, Marin CE, Bjelland I, Haugland BS, Silverman WK, et al. Predictors of treatment outcome in an effectiveness trial of cognitive behavioral therapy for children with anxiety disorders. Behav Res Ther. 2016;76:1-12. doi: 10.1016/j.brat.2015.11.001

16. Markeviciute G, Narbutaite J. Effectiveness of a motivation and practical skills development methods on the oral hygiene of orphans children in Kaunas, Lithuania. J Oral Maxillofac Res. 2015;6(3):e2. doi: 10.5037/jomr.2015.6302

17. Fakhruddin KS, Gorduysus MO, El Batawi H. Effectiveness of behavioral modification techniques with visual distraction using intrasulcular local anesthesia in hearing disabled children during pulp therapy. Eur J Dent. 2016;10(4):551-5. doi: 10.4103/13057456.195159
Received on: 26/1/2017

Final version resubmitted on: 21/3/2017

Approved on: 13/4/2017 